\title{
Three Adnexal Tumors in a Single Lesion: A Case Report
}

\author{
Tek Lezyonda Üç Adneksal Tümör: Olgu Sunumu
}

\section{Elif Sari ${ }^{1}$, Ugur Horoz ${ }^{2}$, Hulda Rifat Ozakpinar ${ }^{2}$, Emre Inozu ${ }^{2}$, Ali Teoman Tellioglu ${ }^{3}$, Bilgihan Acikgoz ${ }^{4}$}

${ }^{1}$ Kirikkale University Faculty of Medicine, Plastic, Reconstructive and Aesthetic Surgery Department, Kirikkale, Turkey

${ }^{2}$ Diskapi Yildirim Beyazit Education and Research Hospital, Plastic, Reconstructive and Aesthetic Surgery Clinic, Ankara, Turkey

${ }^{3}$ Yildirim Beyazit University Faculty of Medicine, Plastic, Reconstructive and Aesthetic Surgery Department, Ankara, Turkey

${ }^{4}$ Diskapi Yildirim Beyazit Education and Research Hospital, Pathology Clinic, Ankara, Turkey

\section{ABSTRACT}

Eccrine poroma is a benign tumor originating from the epidermal sweat duct unitis. Malignant transformation may occur in these lesions, and symptoms of bleeding, pain, and pruritus suggest potential malignancy. Common sites of involvement include plantar, palmar, and acral skin, but eccrine poromas may occur in any skin surface area with sweat glands. Hidroacanthoma simplex, eccrine poroma, dermal duct tumor and poroid hidradenoma are four histopathologic types of poroma or poroid neoplasms. Some authors have reported a combination of two or three of these tumors in a single lesion. As far as we know, the overlapping ecrine ductal tumor that covers eccrine poroma(EP), dermal duct tumor(DDT), and eccrine hidradenoma(EH)] has not been reported in the literature. The aim of this report is to present this rare case.

Key Words: Eccrine poroma, overlap eccrine duct tumor dermal duct tumor, eccrine hidroadenoma

Received: 04.07.2014

Accepted: 05.08.2014

\section{ÖZET}

Ekrin poroma, epidermal ter bezi ünitelerinden kaynaklanan benign bir tümördür. Bu lezyonlarda malignleşme potansiyeli olabilir ve kanama, ağrı ve kaşıntı bulguları potansiyel bir maligniteyi akla getirmektedir. Plantar, palmar ve akral deri sıkça etkilenen alanları içermektedir, fakat ekrin poromalar ter bezleri içeren herhangi bir deri alanında da oluşabilirler. Hidroakantoma simpleks, ekrin poroma, dermal kanal tümörü ve poroid hidradenom poroma poroid neoplazmların 4 tipidir. Bazı yazarlar bu tümörlerden iki ya da üçünün tek bir lezyonda ilişkili olduklarını raporlamışlardır. Bildiğimiz kadarıyla ekrin poroma(EP), dermal kanal tümörü(DDT) ve erkin hidradenom(EH) içeren çakışmış ekrin duktal tümör literatürde yayınlanmamıştır. Bu bildirinin amacı, nadir olan bu olguyu sunmaktır.

Anahtar Sözcükler: Ekrin poroma, çakışan ekrin kanal tümörü, dermal kanal tümörü, ekrin hidradenom

Geliş Tarihi:07.04.2014

Kabul Tarihi: 08.05.2014

\section{INTRODUCTION}

Eccrine poroma was first described in 1956 by Goldman et al. as a benign tumor originating from the epidermal sweat duct unitis(1). These rare tumors typically present as a soft sessile reddish papule or nodule protruding from a cup-shaped depression. Malignant transformation may occur in these lesions, and symptoms of bleeding, pain, and pruritus suggest potential malignancy. Common sites of involvement include plantar, palmar, and acral skin, but eccrine poromas may occur in any skin surface area which contains sweat glands(2). The peak incidence of porocarcinomas is in the seventh decade of life, and they appear to be slightly more common among males than females(3). Also young and child patients have been recently reported in the series(4).

Four histopathologic types of poroma or poroid neoplasm were defined by Abenoza and Ackerman in 1990. They are hidroacanthoma simplex, eccrine poroma, dermal duct tumor and poroid hidradenoma $(\mathrm{PH})(5)$. Some authors have reported the association of two or three of these tumors in a single lesion(6,7). In this paper, a case of an overlapping eccrine duct tumor [ecrine poroma(EP)+ dermal duct tumor(DDT)+ eccrine hidradenoma(EH)] is reported.

\section{CASE REPORT}

A 35-year-old male patient was referred to our clinic with a 3-year history of a continuously growing and frequently bleeding tumor on the back of his thigh (Figure 1). There was no trauma or infection history. Examination revealed a round, erythematous, erosive tumor, approximately $2 \times 2 \mathrm{~cm}$ sized. The patient had no lymphadenopathy or weight loss. The lesion was excised completely with clear surgical margins under local anesthesia. No relapses was detected after a 1 year follow- up. 


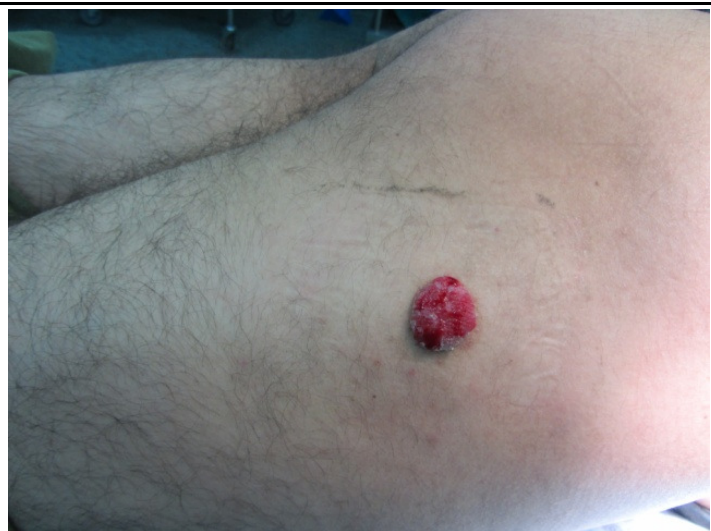

Figure 1. Preoperative view of the lesion. A solitary $2 \times 2 \mathrm{~cm}$ sized red-colored mass on the back of the thigh. It had a rough surface that showed hemorrhagic crusts.

Histological examination was demonstrated ductal differentiations, eccrine and dermal duct tumor islands(Figures 2-4).

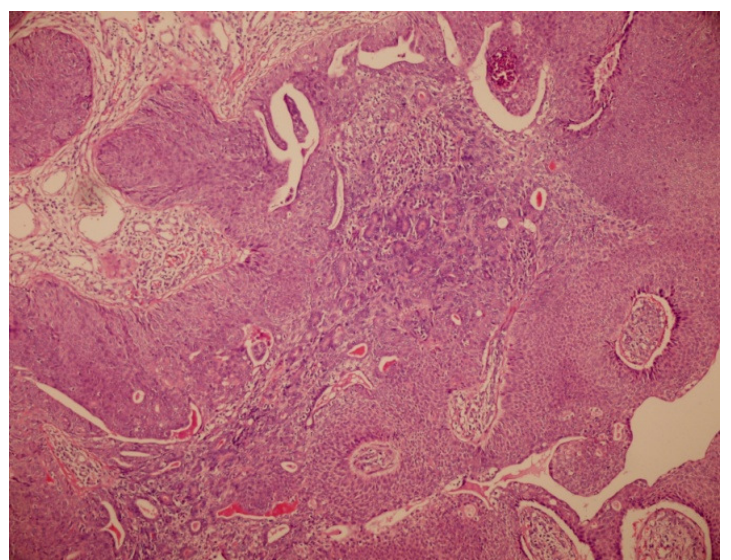

Figure 2. H\&E x200 Ductal differantiation areas of the tumor.

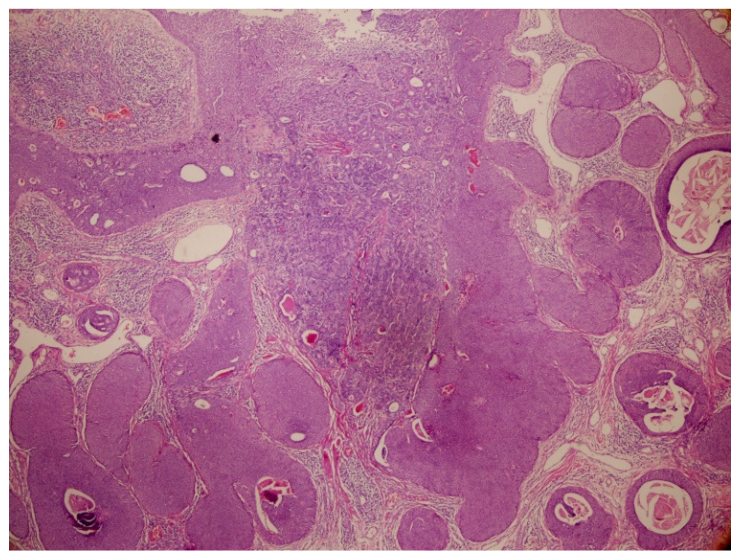

Figure 3. $H \& E \times 100$ Eccrine poroma and dermal duct tumor areas may be seen in this view.

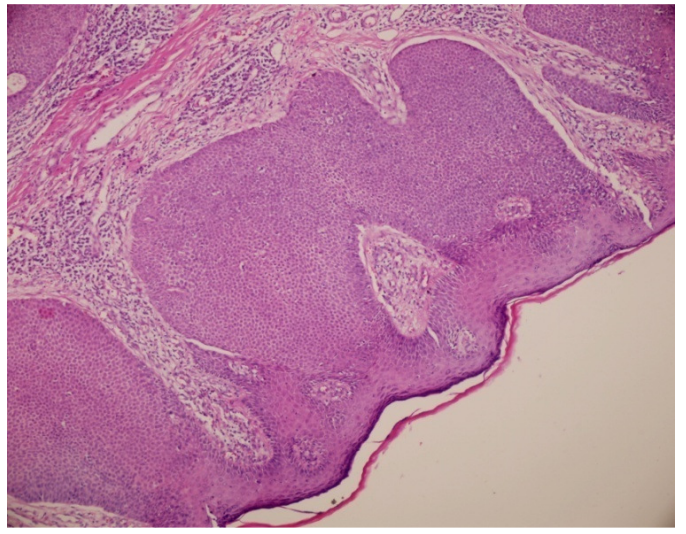

Figure 4. $H \& E x 40$ Eccrine hidradenoma islands that were located near the lesion.

\section{DISCUSSION}

Eccrine poroma is common, benign, slow growing solitary adnexal tumor originating from the intraepidermal portion of the eccrine sweat gland. This malignancy most commonly affects elderly patients, but may also occur at any age(1). Subsequently, many cases have been reported with approximately two thirds of the cases occurring on the sole or on the side of the foot, which is an area with a high concentration of eccrine sweat glands. Other common sites are the hand and finger, with sporadic occurrences on the neck, chest, forehead, nose and scalp(1).

Although eccrine poroma is known to be benign, the variants of eccrine poroma seem to frequently have malignant features. Robson et al. reported that coexistence between benign eccrine poroma and eccrine porocarcinoma is encountered in up to $11 \%$ of the cases(8). Clinically, the neoplasm exhibits an important polymorphism, which can make diagnosis difficult. Wart, pyogenic granuloma, basal cell carcinoma, or intradermal nevus may be suspected. Characteristic histologic findings confirm the diagnosis.

There are several particular subtypes of eccrine poroma. In hidroacanthoma simplex, neoplastic lesions are located entirely within the epidermis. In dermal duct tumor, the neoplasm is located largely or entirely within the dermis. Poroid hidroadenoma consists of a large, sometimes multinodular, aggregation of neoplastic cells with varying proportions of cystic and solid components(9). Because eccrine poromas may recur after incomplete removal and because malignant variants have been described, complete surgical excision is a safe treatment choice. Malignant degeneration may take place in longstanding solitary lesions and cutaneous and fatal visceral metastases have been reported $(10,11)$.

In the literature eccrine poroma with poroid hidradenoma, eccrine poroma with eccrine porocarcinoma, poroma with sebaceous differentiation, eccrine poroma with dermal duct tumor and hidroacanthoma simplex in the single lesions were reported $(6,12)$. But as far as we know, an overlap of eccrine poroma with ductal duct tumor and eccrine hidradenoma was not reported before. Therefore, this triple combination should be kept in mind and wide excisions should be done for the treatment.

\section{Conflict of Interest}

No conflict of interest was declared by the authors.

\section{REFERENCES}

1. Kang MC, Kim SA, Lee KS, Cho JW. A Case of an Unusual Eccrine Poroma on the Left Forearm Area. Ann Dermatol 2011; 23: 250-3.

2. Jagdeo J, Robinson-Bostom L, Long $T$. Unusual clinical presentation of benign eccrine poroma. J Am Acad Dermatol 2006; 54: 733-4.

3. Gerber PA, Schulte KW, Ruzicka $T$, Bruch-Gerharz D. Eccrine Porocarcinoma of the Head: An Important Differential Diagnosis in the Elderly Patient. Dermatology 2008;216:229- 33.

4. Orlandı C, Arcangeli F, Patrizi A, Neri I. Eccrıne Poroma in a Child Pediatric Dermatology 2005; 22: 279- 80.

5. Abenoza $P$, Ackerman AB. eds. Poromas. In Neoplasms with eccrine differentiation.Philadelphia, PA: Lea\&Febiger, 1990; 113.

6. Kakinuma H, Miyamoto R, Iwasawa U, Baba S, Suzuki H. Three subtypes of poroid neoplasia in a single lesion: eccrine poroma, hidroacanthoma simplex, and dermal duct tumor. Histologic, histochemical, and ultrastructural findings. Am J Dermatopatho 1994; 16: 66.

7. Misago N, Kohda H. A single lesion demonstrating features of eccrine poroma and poroid hidradenoma. J Dermatol 1995; 22: 773.

8. Robson A, Greene J, Ansari N, Kim B, Seed PT, McKee PH et al. Eccrine porocarcinoma (malignant eccrine poroma): a clinicopathologic study of 69 cases. Am J Surg Pathol 2001; 25: 710- 20.

9. Harada T, Mıyamoto T, Takahashı M, Tsutsumı Y. Eccrine poroma in the external auditory canal. Otolaryngology - Head and Neck Surgery. 2003; 128: 439.

10. Valverde K, Senger C, Ngan BY, Chan HS. Eccrine porocarcinoma in a child that evolved rapidly from an eccrine poroma. Med Pediatr Oncol 2001;37: 412- 4.

11. Labbé $D$, Harbon $S$, Dompmartin A, Mandard JC, Leroy $D$ Compere JF. Malignant eccrine poroma. Apropos of two facial sites. Ann Chir Plast Esthet 1989;34: 146- 52.

12. Chiu HH, Lan $\mathrm{CCH}$, Wu CS, Chen GS, Tsai KB, Chen PH. A single lesion showing features of pigmented eccrine poroma and poroid hidradenoma. J Cutan Pathol 2008: 35: 861- 5. 